\title{
Glycoprotein C Gene of Caprine Herpesvirus Type 1 Contains Short Sequence Repeats (SSR)
}

\author{
Elvira Tarsitano, Michele Camero, Anna Lucia Bellacicco, Nicola Decaro, Vito Martella, \\ Canio Buonavoglia and Maria Tempesta*
}

Department of Veterinary Public Health, Faculty of Veterinary Medicine, University of Bari, Bari, Italy

\begin{abstract}
Caprine herpesvirus $1(\mathrm{CpHV}-1)$ is responsible for vaginal and respiratory disease in goats. Infection by vaginal route is usually restricted to the genital tract whereas by nasal route the virus can spread throughout the body. In order to evaluate genomic diversity, nucleotide sequences of glycoprotein $\mathrm{C}$ ( $\mathrm{gC}$ ) of 13 (n.8 vaginal, n.5 nasal) $\mathrm{CpHV}-1$ strains were analyzed. Amino acid (aa) sequences showed a variable number of short sequence repeats (SSR). Nucleotide and amino acid sequences of amplified products showed to contain a variable number of short sequence repeats among the examined strains. These results indicated that $\mathrm{CpHV}-1$ isolates had genetic diversity in the gC gene regarding the number of SSR: 4 SSR of $60 \mathrm{bp}$ in one strain, 2 SSR of $30 \mathrm{bp}$ in seven strains and $1 \mathrm{SSR}$ of $15 \mathrm{bp}$ in three strains. Two strains had no SSR.
\end{abstract}

Keywords: Short sequence repeats, genetic diversity, glycoprotein C, caprine herpesvirus 1.

\section{INTRODUCTION}

Caprine herpesvirus type $1(\mathrm{CpHV}-1)$ is an $\alpha$-herpesvirus of goats sharing several biological behaviours with human herpesvirus type 2 (HHV-2), i.e., genital lesions, latency in sacral ganglia [1]. CpHV-1 is responsible for systemic lethal infections in kids [2] and respiratory or genital infections in adult goats [3]. CpHV-1 can be isolated from the nose and/or vagina of infected animals. Natural or experimental infection may occur both via nasal and/or genital route $[4,5]$. When the virus infects goats by the nose, the infection can spread throughout the body and reach the genital mucosa. The infection by the vaginal route remains restricted to the genital tract $[4,6]$. No differences have been observed among nasal or vaginal isolates using virus neutralization test. Italian, Swiss, American and Spanish CpHV-1 strains, have been analysed by Restriction Fragment Length Polymorphism (RFLP), showing differences in the restriction patterns: i.e. altered sizes of single fragments, lacking or additional fragments [7-9].

In order to evaluate genomic diversity of the isolates, nucleotide and amino acid sequences of glycoprotein $\mathrm{C}(\mathrm{gC})$, were analyzed in thirteen $\mathrm{CpHV}-1$ strains.

\section{MATERIAL AND METHODS}

\section{Strains}

Thirteen CpHV-1 strains were analyzed in this study: eight vaginal and five nasal isolates. As reported in Table 1, the viruses were isolated in natural or experimental reactivations of $\mathrm{CpHV}-1$ in geographically and timely different caprine flocks.

*Address correspondence to this author at the Department of Veterinary Public Health, Faculty of Veterinary Medicine, University of Bari, Str. Prov. Casamassima Km 3, 70010, Valenzano, Bari, Italy; Tel: +39-080-4679838; Fax: +39-080-4679843; E-mail: m.tempesta@veterinaria.uniba.it
Table 1. CpHV-1 Strains Used in this Study

\begin{tabular}{|l|l|l|}
\hline \multicolumn{1}{|c|}{ Strains } & \multicolumn{1}{|c|}{ Recovery } & \multicolumn{1}{c|}{ Origin } \\
\hline \hline 1. Carica & nose & Experimental reactivation \\
2. Ba-3 & nose & Experimental reactivation \\
3. Ba-2 & vagina & Experimental reactivation \\
4. 2760 & vagina & Natural reactivation \\
5. 5175 & vagina & Natural reactivation \\
6. Ba- 6 & vagina & Experimental reactivation \\
7. TV 16 & vagina & Experimental reactivation \\
8. Usa & nose & Experimental infection \\
9. Sicilia & vagina & Experimental reactivation \\
10. 1347 & vagina & Natural reactivation \\
11. Svizzero & nose & Experimental infection \\
12. Ba-1 & vagina & Experimental reactivation \\
13. TN 7 & nose & Experimntal reactivation \\
\hline
\end{tabular}

\section{Extraction of Viral DNA}

DNA was extracted from the original nasal and vaginal samples using the Qiamp Tissue Kit (Qiagen $\mathrm{GmbH}$, Germany) according to the instructions of the manufacturer and stored at $+4^{\circ} \mathrm{C}$.

\section{Amplification of gC Gene}

The glycoprotein $\mathrm{C}$ gene was amplified by polymerase chain reaction (PCR). Primers (Nik1 and Nik2) specific for CpHV-1 [10] and internal primers (CB3F and CB3R) were used for the amplification of $1800 \mathrm{bp}$ and $400 \mathrm{bp}$ fragment respectively of the $\mathrm{gC}$ gene. The internal primers were used to point out the short sequence repeats (SSR), as reported in Table 2.

The total volume of the PCR reaction was $50 \mu 1$, which contained $10-50 \mathrm{ng}$ extracted DNA, $1 \mathrm{X}$ buffer $(100 \mathrm{mM}$ Tris- 
$\mathrm{HCl}, \mathrm{pH} 8.3$ and $500 \mathrm{mM} \mathrm{KCl}), 25 \mathrm{mM} \mathrm{MgCl}_{2}, 1.25 \mathrm{mM}$ dNTP, 50pmol of each primer and 1.25 units of TaKaRa LA $T_{a q}{ }^{T M}$ (TAKARA BIO INC.) in distilled water. The PCR programme was $94^{\circ} \mathrm{C}$ for $1 \mathrm{~min}\left(\right.$ TaKaRa LA Taq ${ }^{T M}$ activation temperature), followed by 35 cycles of $1 \mathrm{~min}$ and $30 \mathrm{sec}$ at $95^{\circ} \mathrm{C}, 1,00 \mathrm{~min}$ at $60^{\circ} \mathrm{C}$ and $2 \mathrm{~min}$ and $30 \mathrm{sec}$ at $72^{\circ} \mathrm{C}$, and it was terminated with an extension at $72^{\circ} \mathrm{C}$ for 10 min (Thermocycler Applied Biosystems Gene Amp PCR system 9700). The PCR products were electrophoresed in $1.4 \%$ agarose gels (Ambion) in TAE buffer and visualised under UV light after ethidium bromide staining $(10 \mathrm{mg} / \mathrm{ml})$. GeneRuler $^{T M} 50$ bp DNA Ladder (Fermentas) was used as molecular weight standard.

Table 2. Primers Sequences

\begin{tabular}{|l|}
\hline Nik1 (forward) 5' -gCTAgggCTCTgCACgTC- 3' \\
\hline Nik2 (reverse) 5' - gCCATTgAAAgggTTACgTC- 3' \\
\hline CB3F (forward) 5' -AgTTgACgTACAACgggTCggCgTA- 3' \\
\hline CB3R (reverse) 5' - AgAgCAgCgAAgAgggCgACgA- 3' \\
\hline
\end{tabular}

\section{Sequence Analysis}

The PCR products were purified in Ultrafree-DA columns (Amicon, Millipore) and sequenced using the Taq DyeTerminator Cycle Sequencing Kit (Applied Biosystems) with an ABIPRISM 377. Sequences were aligned for the same strain. The nucleotide and amino acid sequences were read using the analytical tools by the National Center for Biotechnology Information (NCBI) and align by the program CLUSTALW and FASTA [11].

\section{RESULTS}

PCR products had a size ranging from $400 \mathrm{bp}$ to $464 \mathrm{bp}$ using primers $\mathrm{CB} 3 \mathrm{~F}$ and $\mathrm{CB} 3 \mathrm{R}$. The amplified fragments show that the nucleotide sequences had a different molecular weight as described in Fig. (1).

The nucleotide sequences of the amplified products showed a variable number of short sequence repeats (SSR), each containing 15 nucleotides, among the examined strains: 4 SSR in one strain (nasal), 2 SSR in seven strains (n.5 vaginal, n.2 nasal) and $1 \mathrm{SSR}$ in three strains (n.2 vaginal, n.1 nasal). Two strains had no SSR (n.1 vaginal, n.1 nasal), (Table 3). At the protein level, the SSR corresponded to the amino acid stretch FEDSA, ENDGA, KEDGA or KEDSA on the basis of the analyzed strain (Fig. 2).

\section{DISCUSSION}

The SSR in the family of Herpesviridae genomes play diverse roles, including modulating gene expression as contingency loci, facilitating genome rearrangements via recombination and affecting protein structure and possibly protein-protein interactions [12-16]. Genetic variations and classification into different genogroups have been described for other herpesviruses, such as bovine herpesvirus type 1 (BHV-1), [17], varicella-zoster virus [18], simian varicella virus [19] Epstein-Barr virus [20, 21], cytomegalovirus [22, 23], and human herpesviruses 6 and 7 [24, 25]. As reported by Norberg et al. [26], DNA sequencing of large regions from the clinical HHV-1 isolates may be helpful in revealing genetic alterations associated with $\mathrm{HHV}-1$ pathogenesis and may be used for molecular epidemiology studies of different viral populations as well as for studies of single patient isolates and to investigate the role of homologous recombination in the evolution of the HHV-1 genome.

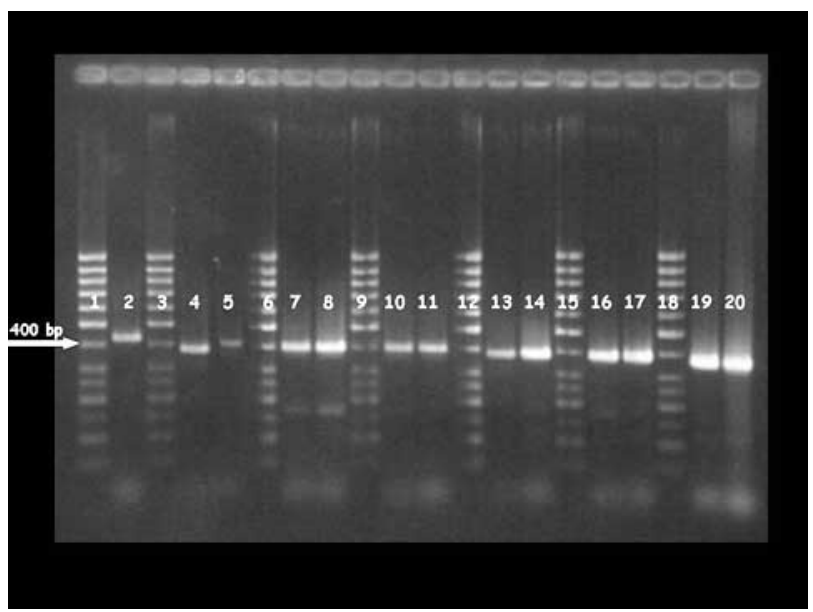

Fig. (1). PCR products of CpHV-1 strains using two internal primers (CB3F-CB3R) of gC gene. Lanes 1, 3, 6, 9, 12, 15, 18: 50 bp DNA ladder plus (Fermentas); lane 2: Carica (464 bp); lane 4: Ba-3 (433 bp); lane 5: Ba-2 (449 bp); lane 7: 2760 (436 bp); lane 8: 5175 (437 bp); lane 10: Ba-6 (432 bp); lane 11: TV16 (430 bp); lane 13: Usa (434 bp); lane 14: Sicilia (428 bp); lane 16: 1347 (419 bp); lane 17: Svizzero (415 bp); lane 19: Ba-1 (405 bp); lane 20: TN7 (400 bp).

Nucleotide and amino acid sequence analysis indicate that $\mathrm{CpHV}-1$ isolates have genetic diversity in the $\mathrm{gC}$ gene according to the number of SSR detected (4 SSR of $60 \mathrm{bp}$ in one strain, 2 SSR of $30 \mathrm{bp}$ in seven strains and 1 SSR of 15 $\mathrm{bp}$ in three strains). Variable regions containing SSR have been also reported in HHV-1 [27, 28]. On the basis of few information available, it may be supposed that $\mathrm{CpHV}-1$ isolates are characterized by high $\mathrm{G}+\mathrm{C}$ content and presence of nucleotides repeats in the sequences of glycoprotein $\mathrm{C}$ gene. Genetic rearrangements (SSR) in the $\mathrm{gC}$ gene, may be useful for differentiation of $\mathrm{CpHV}-1$ strains as reported for feline herpesvirus type 1 (FeHV-1) [29] and further studies

Table 3. Analysis of gC Gene of CpHV-1 Strains

\begin{tabular}{|c|c|c|c|}
\hline Number of Strains & Number of Short Sequence Repeats (SSR) & Total of Inserted Nucleotides (bp) & Sampling Origin \\
\hline \hline 1 & 4 & 60 & nasal \\
\hline 7 & 2 & 30 & $\mathrm{n} .5 \mathrm{vaginal}, \mathrm{n} .2 \mathrm{nasal}$ \\
\hline 3 & 1 & 15 & $\mathrm{n} .2 \mathrm{vaginal}, \mathrm{n} .1 \mathrm{nasal}$ \\
\hline 2 & 0 & - & $\mathrm{n} .1 \mathrm{vaginal}, \mathrm{n} .1 \mathrm{nasal}$ \\
\hline
\end{tabular}




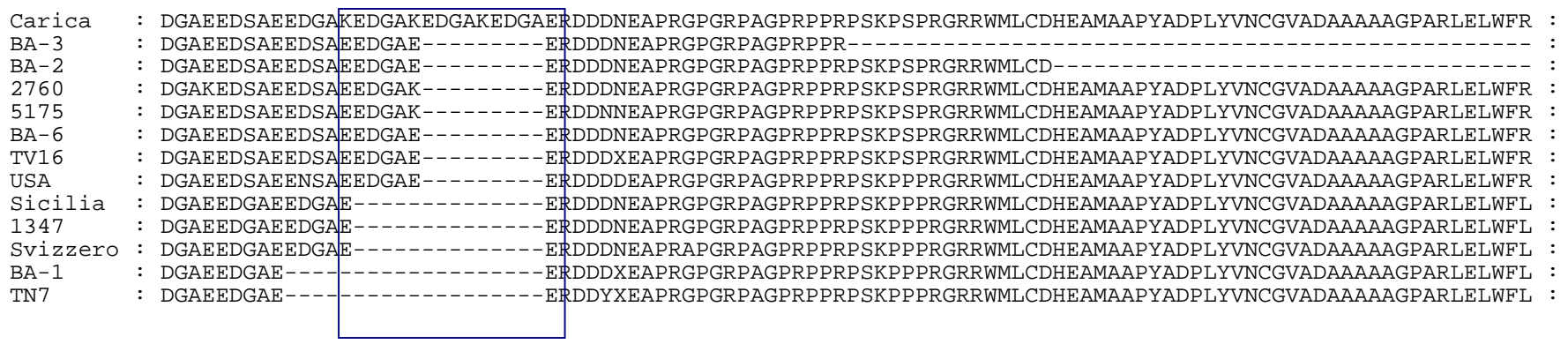

Fig. (2). Alignment of the glycoprotein $\mathrm{C}(\mathrm{gC})$ gene. It is possible to observe the short sequence repeats (SSR) drawn based on the number of insertions. Box shows the SSR. Carica has 4 SSR, Ba-3, Ba-2, 2760, 5175, Ba-6, TV16 and USA 2 SSR, Sicilia, 1347 and Svizzero 1 SSR; Ba-1 and TN7 have no SSR.

will also elucidate whether the SSR number is related to any biological feature of $\mathrm{CpHV}-1$ i.e. the nasal or the vaginal tropism.

\section{ACKNOWLEDGEMENT}

This work was supported by grants from University of Bari, Italy project PRIN2007.

\section{REFERENCES}

[1] Tempesta M, Pratelli A, Greco G, Martella V, Buonavoglia C. Detection of caprine herpesvirus 1 in sacral ganglia of latently infected goats by PCR. J Clin Microbiol 1999; 37: 1598-9.

[2] Roperto F, Pratelli A, Guarino G, et al. Natural caprine herpesvirus 1 (CpHV-1) infection in kids. J Comp Pathol 2000; 122: 298-302.

[3] Horner GW, Hunter R, Day AM. An outbreak of vulvovaginitis in goats caused by a Caprine herpesvirus N Z Vet J 1982; 30: 150-2.

[4] Tempesta M, Pratelli A, Corrente M, Buonavoglia C. A preliminary study on the pathogenicity of a strain of caprine herpesvirus-1. Comp Immun Microbiol Infect Dis 1999; 22: 137-47.

[5] Tempesta M, Pratelli A, Normanno G, et al. Experimental intravaginal infection of goats with caprine herpesvirus 1 . J Vet Med B Infect Dis Vet Public Health 2000; 47: 197-201.

[6] Tempesta M, Buonavoglia D, Greco G, et al. A study on the infection and reactivation of caprine herpesvirus 1 in goats. Proceedings of the $7^{\text {th }}$ International Conference on Goat; 2000 May 15-18; Tours, France.

[7] Keuser V, Espejo-Serrano J, Schynts F, Georgin JP, Thiry E. Isolation of Caprine herpesvirus 1 in Spain. Vet Rec 2004; 154: 395-9.

[8] Pratelli A, Greco G, Dall'ara P, Engels M, Tempesta M, Buonavoglia C. Restriction endonuclease analysis of the genome of two Italian Caprine Herpesvirus 1 strains. Arch Virol 2000; 145: 845-51.

[9] Rocchigiani AM, Puggioni G, Murtino AP, et al. Isolamento e caratterizzazione di un ceppo di Caprine Herpesvirus 1 in Sardegna. Proceedings III Workshop Virologia Veterinaria 2009 June 11-12; Bari, Italy.

[10] Hecht P, Engels M, Loepfe E, Ackermann M. Comparison of the glycoprotein $\mathrm{gC}$ genes of bovine and caprine herpesviruses. In: Immunobiology of Viral Infections. Proceedings of the $3^{\text {rd }}$ Congress European Society Veterinary Virology; 1995 September 4-7; Interlaken, Switzerland.

[11] Thompson JD, Higgins DG, Gibson TJ. Clustal W. Improving the sensitivity of progressive multiple sequence alignment through sequence weighting, position-specific gap penalties and weight matrix choice. Nucleic Acids Res 1994; 22: 4673-80.

[12] Riley DE, Krieger JN. Diverse eukaryotic transcripts suggest short tandem repeats have cellular functions. Biochem Biophys Res Commun 2002; 298: 581-6.
[13] Riley DE, Krieger JN. Transcribed short tandem repeats occur in couples with strongly preferred registers. Biochem Biophys Res Commun 2003; 305: 257-65.

[14] Riley DE, Krieger JN. Short tandem repeats are associated with diverse mRNAs encoding membrane-targeted proteins. Bioessays 2004; 26: 434-44.

[15] Riley DE, Krieger JN. Simple repeat replacements support similar functions of distinct repeats in inter-species mRNA homologs. Gene 2004; 328: 17-24.

[16] Tan BT, Warnke RA, Arber DA. The frequency of B- and T-cell gene rearrangements and epstein-barr virus in T-cell lymphomas: a comparison between angioimmunoblastic T-cell lymphoma and peripheral T-cell lymphoma, unspecified with and without associated B-cell proliferations. J Mol Diagn 2006; 8: 466-75.

[17] Wang J, Horner GW, O'keefe JS. Genetic characterisation of Bovine Herpesvirus 1 in New Zealand. NZ Vet J 2006; 54: 61-6.

[18] Muir WB, Nichols R, Breuer J. Phylogenetic analysis of varicella-zoster virus: evidence of intercontinental spread of genotypes and recombination. J Virol 2002; 76: 1971-9.

[19] Mahalingam R, Gray WL. The simian varicella virus genome contains an invertible 665 base pair terminal element that is absent in the varicella zoster virus genome. Virology 2007; 366: 387-93.

[20] Sample J, Young L, Martin B, Chatman T, Kieff E, Rickinson A Epstein-Barr virus types 1 and 2 differ in their EBNA-3A, EBNA-3B, and EBNA-3C genes. J Virol 1990; 64: 4084-92.

[21] Kim IJ Burkum CE, Cookenham T, Schwartzberg Pl, Woodland Dl, Blackman MA. Perturbation of B cell activation in SLAM-associated protein-deficient mice is associated with changes in gammaherpesvirus latency reservoirs. J Immunol 2007; 178: 1692-701.

[22] Chou S. Comparative analysis of sequence variation in gp116 and gp55 components of glycoprotein B of human cytomegalovirus. Virology 1992; 188: 388-90.

[23] Chou SW, Dennison KM. Analysis of interstrain variation in cytomegalovirus glycoprotein B sequences encoding neutralizationrelated epitopes. J Infect Dis 1991; 163: 1229-34.

[24] Clark D A. Human herpesvirus 6. Rev Med Virol 2000; 10: 155-73.

[25] Franti M, Aubin JT, Poirel L, et al. Definition and distribution analysis of glycoprotein B gene alleles of human herpesvirus 7. J Virol 1998; 72: 8725-30.

[26] Norberg P, Bergström T, Rekabdar E, Lindh M, Liljeqvist JA. Phylogenetic analysis of clinical herpes simplex virus type 1 isolates identified three genetic groups and recombinant viruses. J Virol 2004; 78: $10755-64$

[27] Umene K. Mechanism and application of genetic recombination in herpesviruses. Rev Med Virol 1990; 9: 171-82.

[28] Umene K. Herpesvirus: genetic variability and recombination. Touka Shobou, Fukuoka; 1998

[29] Hamano M, Maeda K, Mizukoshi F, et al. Genetic rearrangements in the $\mathrm{gC}$ gene of the feline herpesvirus type 1 . Virus Genes 2004; $28: 55$ 60 . 